\title{
The Foreign Exchange Exposure of Non-Financial Companies in Eurozone: Myth or Reality?
}

\author{
Ramona Rupeika-Apoga ${ }^{1}$, Roberts Nedovis ${ }^{2}$
}

\begin{abstract}
:
The authors of this paper are looking for answers: are domestic companies operating in small market economies such as the Baltics with little or no direct foreign involvement also at risk, taking into account that our companies mainly as a mean of exchange are using euro.

The aim of this study is to examine the foreign exchange rate exposure of domestic corporations in the Baltic States. The study shows that companies in the Baltic States tend not to manage their foreign exchange risk properly and some of the companies are thus exposed to significant losses due to fluctuations in currency exchange rates. The VaR estimates are proposed and evaluated as a method to measure the position that is necessary to hedge.
\end{abstract}

Key Words: foreign exchange risk, risk measuring and exposure, VaR methods, nonfinancial companies

JEL code: G32, F31.

\footnotetext{
${ }^{1}$ University of Latvia, corresponding author - e-mail: $\underline{\text { rr@lu.lv }}$

${ }^{2}$ University of Latvia
} 


\section{Introduction}

In an increasingly globalizing world, companies in small open economies such as Baltic are not isolated from the effects of international economic cycles, currency movements, and global competition. Since mid-2008, foreign exchange markets have become more volatile due to the financial crisis in 2008 and the currency wars. Between mid-2012 and mid-2014, the euro increased in value by $10 \%$ compared to other currencies, but this trend has reversed over the last six months, and the effective exchange rate has fallen by $5.2 \%$. Between spring 2014 and late January 2015, the euro depreciated by almost 20\% against the US dollar and by about $10 \%$ against the British pound, driven by increasingly diverging monetary policy stances and growth dynamics. Generally, risk contribution from unhedged currency exposures could be higher than it used to be in the past. For this reason foreign exchange risk management may be more of a priority than ever.

Nowadays companies face the challenge of evaluating the potential loss of transactions, especially in light of the recent financial crisis that showed what can happen as a result of poor risk management policy. Value-at-Risk (VaR) holds a special place in the risk management - it is used almost everywhere. VaR is particularly important because it is used to calculate the market risk component of regulatory capital under the Basel Committee and it is one of the most applied risk measure in investment portfolio theory, financial control and financial reporting as well. In this paper the authors have applied VaR methods for non-financial companies' foreign exchange exposure measurement.

As a misleading $\mathrm{VaR}$ estimate can lead to bad judgement on foreign exchange exposure and, consequently, to bad risk management, there is a need for an examination of $\mathrm{VaR}$ applications in the context of Baltic non-financial companies. The measure of foreign exchange exposure lies in the variety of difficulties. First of all, there is no single unambiguous method of risk assessment, as different methods may produce different results. Secondly, each method has its own faults.

The object of this research is foreign exchange risk measurement and management for the Baltic States companies.

The purpose of this research is by analysing different issues relating to the measurement and management of foreign exchange exposure to propose Baltic companies better ways to manage their outstanding currency positions.

To achieve the purpose the following tasks were conducted:

1. Analysis of the theoretical aspects of the measuring and managing currency exposure. 
2. Analysis of Baltic companies' financial reports data to clarify risk management activities.

3. Clarifying firms' attitudes towards foreign exchange risk management in the Baltic States.

4. Estimating different VaR methods to measure foreign exchange exposure.

5. Development of recommendation how Baltic companies should manage their outstanding currency positions.

The research methodology used in this paper is generally accepted qualitative and quantitative methods of economic research, including Value-at-Risk (VaR) methods to measure risks for different horizons and by testing different observation periods of open positions. The paper starts with a literature review in order to highlight the difficulties faced by non-financial companies in identifying, measuring and managing foreign exchange risk. The analysis conducted in this paper is based on companies' financial reports' data and statistics, and certain empirical studies. The data set is based on firms that were publicly listed on NASDAQ OMX Baltic Stock Exchange Main list. Baltic Regulated market is the primary market of the NASDAQ OMX Baltic exchanges, which is regulated under EU directives and is under the supervision of the national FSA. The listing requirements are based on European standards and EU directives, and intended for companies that are well established. The regulatory demands on the regulated market are higher than on First North. The Baltic Main List is a line-up of all blue-chip companies listed on the Tallinn, Riga and Vilnius stock exchanges. To be eligible for inclusion, a company must have 3 years of operating history, an established financial position, market cap of not less than EUR 4 million, with reporting according to the International Financial Reporting Standards, and a free float equal or greater than the minimum of $25 \%$ of market cap and EUR 10 million. The Baltic Secondary List comprises companies that do not meet quantitative admission requirements (free float, capitalization). The admission requirements are not as strict compared with those of the Baltic Main List. The authors have chosen for research companies listed in main list for the period spanning 2008 to 2013, excluding financial companies-banks. There were 34 companies listed on NASDAQ OMX Baltic exchanges main list in 2013, including a bank (Šiauliu bankas). Over the analysed period some companies have left the main list (as Trigon Property Development, Sanitas) others have joined (Lietuvos energijos, LESTO, Linas agro) as a result 33 companies were chosen for analysis. The data were taken from the Nasdaq website.

\section{Research results and discussion}

\section{Literature review and hypotheses}

\subsection{Exposure measurement}


Nevertheless that the appropriateness of value-at-risk ( $\mathrm{VaR})$ methodology as a risk measure has been questioned in variety of studies and surveys (Bawa, V. 1978; Pedersen C. and Satchell S., 1998; Artzner, P. et al., 1999; Dowd. K, 2002; Gallati R., 2003) it is still the most popular risk assessment tool (Jorion, P. 2001, 2006; Bao, Y., Lee, T.-H. and B. Saltoglu, 2004; Pritsker, M. 1997, 2001). As proposed by the Basle Committee on Banking Supervision, banks are now allowed to calculate capital requirements for their trading books and other involved risks based on a VaR concept (Basle, 1995) and (Basle, 1996 (a,b)) and in Basel committee VaR is recognized as the most comprehensive benchmark for risk measurement.

The VaR concept has emerged as the most prominent measure of downside market risk. It places an upper bound on losses in the sense that these can exceed the VaR threshold with only a small target probability, typically chosen between $1 \%$ and $5 \%$. The VaR can be used to measure potential foreign exchange exposure by calculating possible losses from unhedged positions. $\mathrm{VaR}$ is an estimate of the worst possible loss (i.e., the decrease in the market value of a foreign exchange position) a position could suffer over a given time horizon, under normal market conditions (defined by a given level of confidence). The VaR measure of exchange rate risk is used by companies to estimate the exposure of a foreign exchange position resulting from a company's activities over a certain time period under normal conditions.

The VaR calculation depends on 3 parameters:

- The holding period, i.e., the length of time over which the foreign exchange position is planned to be held. The typical holding period is 1 day for financial institutions, but as in this research we analysed non-financial companies the holding period starts from 1 month to 12 months.

- The confidence level at which the estimate is planned to be made. The usual confidence levels are 99 percent and 95 percent.

- The unit of currency to be used for the denomination of the VaR.

VaR can be estimated either parametrically (for example, variance-covariance VaR or delta-gamma $\mathrm{VaR}$ ) or nonparametrically (for example, historical VaR or resampled VaR). Nonparametric methods of $\mathrm{VaR}$ estimation are discussed in $\mathrm{N}$. Markovich (2007) and S. Y. Novak (2011). Literature analysis reveals that VaR estimation results vary widely depending on the methodology and that no VaR model is adequate in all situations (Kuester, Mittnik and Paolella, 2006). In this paper the authors are testing following VaR methods: historical, delta approximation method and GARCH.

For practical implementation of Value-at-Risk methods the authors used M. Taqqu and B. Bradley (2001), P. Jorion (2001) and P. Embrechts, A. McNeil and R. Frey (2005) works.

Practical VaR measure implementation assumes a statistical model for the data. Different underlying models lead to different VaR estimates. Our first hypothesis 
concerns the robustness of VaR methods towards underlying models, whereas the second hypothesis states that in general VaR methods can be successfully used to measure potential foreign exchange exposure.

H1: VaR methods of risk assessment give similar results.

H2: VaR can be effectively used to measure the part of the currency position that should be hedged.

\subsection{Risk management}

The scope of the exchange rate risk management literature is very broad. Modern finance and economics have been concerned with the effects of changes in exchange rates on returns and cash flows of corporations (Aggarwal R. \& Harper J., 2010). Companies' managers are often challenging with dilemma of choosing between the tasks of increased profits and reduced exchange losses. Moreover, reducing one kind of exposure, for example translation, might lead to an increase in another kind of exposure, for example transaction exposure, and vice versa. These and similar questions demonstrate the need for a coherent and effective strategy (Allayannis $e t$ al., 2001; Froot et al., 1993; Bartov E. and Bodnar G., 1994; Thalassinos et al., 2010 ; Thalassinos et al., 2012 and Thalassinos et al., 2014 and 2015).

In general all management strategies can be divided into two big groups: internal and external strategies. The internal strategy includes all the techniques that do not require external parties, whereas external hedging strategy deals mainly with financial contracts such as futures, forwards, options and swaps. When choosing between different types of hedging, manager must compare costs, taxes, effects on accounting conventions and regulation. As external hedging instruments companies prefer to use OTC instruments (forward, swaps, and options) rather than exchange traded instruments such as futures (Bodnar G. and Gebhardt G., 1998). Companies also prefer to use the simplest hedging instruments, mostly using forward agreements instead of options and swaps (Bodnar G., Marston R. and Hayt G., 1998; Batten et. al., 1993). Mostly external hedging strategies are used by companies with foreign sales, in contrast, the percentage of firms with no foreign sales that use foreign currency derivatives is rather small (Allayannis G. and Weston J., 2001; Thalassinos, Liapis and Thalassinos, 2014).

Our third hypothesis concerns the hedging techniques that are most popular within the Baltic States companies.

H3: Baltic companies are mostly using internal hedging techniques.

2. Empirical Results

2.1. Exposure measurement 
There are different methods of $\mathrm{VaR}$ estimation. In the paper we used three estimation methods - historical, delta approximation method and GARCH. In VaR estimation by historical method data are sorted in ascending order and $\alpha \cdot n$th observation, where $\alpha$ is VaR significance level, is taken as an estimate of VaR. The main advantages of the method are that it does not make any assumptions on distribution function of the data and is easy to calculate. In delta approximation method it is assumed that the data are normally distributed with estimated mean and variance parameters. The $\mathrm{VaR}$ estimate equals the $\alpha$-quantile of the normal distribution with relevant parameters. GARCH estimation method is based on assumption that data are taken from $\operatorname{GARCH}(\mathrm{q}, \mathrm{p})$ process, that is (Bera A. and Higgins M., 1993)

$$
\begin{gathered}
x_{t}=\mu_{t}+\sigma_{t} \varepsilon_{t,} \\
\sigma_{t}^{2}=\alpha_{0}+\alpha_{1} x_{t-1}^{2}+\cdots+\alpha_{q} x_{t-q}^{2}+\beta_{1} \sigma_{t-1}^{2}+\cdots+\beta_{p} \sigma_{t-p}^{2}
\end{gathered}
$$

In the paper $\operatorname{GARCH}(1,1)$ process specification was used.

As mentioned above VaR risk measure depends on several factors such as confidence level and outstanding position's holding period. Tables 1-3 show that VaR estimates by historical, delta and GARCH methods give very similar VaR results and so estimation method is less important for $\mathrm{VaR}$ estimation than parameters such as significance level and holding period. VaR values are greater for longer holding periods and bigger significance levels.

For estimation of foreign exchange risk we've used monthly exchange rates published by the Bank of Latvia for period from January 1999 (introduction of the euro) to January 2014.

Table 1. Estimated VaR for a position of 1 currency unit of foreign currency in EUR for various currencies, holding periods and confidence level $90 \%$

\begin{tabular}{|c|c|c|c|c|c|c|}
\hline Significance level & \multicolumn{7}{|c|}{$90 \%$} \\
\hline 1 month & BYR & PLN & RUB & SEK & UAH & USD \\
\hline VaR historical & $0.000 \%$ & $-0.771 \%$ & $-0.042 \%$ & $-0.259 \%$ & $-0.300 \%$ & $-1.873 \%$ \\
\hline VaR delta & $-0.004 \%$ & $-0.834 \%$ & $-0.054 \%$ & $-0.285 \%$ & $-0.368 \%$ & $-2.258 \%$ \\
\hline VaR GARCH & $-0.001 \%$ & $-0.706 \%$ & $-0.072 \%$ & $-0.248 \%$ & $-0.203 \%$ & $-1.305 \%$ \\
\hline 3 months & & & & & & \\
\hline VaR historical & $0.000 \%$ & $-1.158 \%$ & $-0.066 \%$ & $-0.422 \%$ & $-0.482 \%$ & $-2.679 \%$ \\
\hline VaR delta & $-0.005 \%$ & $-1.432 \%$ & $-0.085 \%$ & $-0.495 \%$ & $-0.582 \%$ & $-3.818 \%$ \\
\hline VaR GARCH & $-0.001 \%$ & $-1.303 \%$ & $-0.108 \%$ & $-0.456 \%$ & $-0.346 \%$ & $-2.317 \%$ \\
\hline 6 months & & & & & & \\
\hline
\end{tabular}


The Foreign Exchange Exposure of Non-Financial Companies in Eurozone: Myth or Reality?

60

\begin{tabular}{|c|c|c|c|c|c|c|}
\hline VaR historical & $0.000 \%$ & $-1.424 \%$ & $-0.091 \%$ & $-0.718 \%$ & $-0.528 \%$ & $-5.232 \%$ \\
\hline VaR delta & $-0.006 \%$ & $-2.008 \%$ & $-0.109 \%$ & $-0.699 \%$ & $-0.748 \%$ & $-5.274 \%$ \\
\hline VaR GARCH & $-0.003 \%$ & $-1.917 \%$ & $-0.130 \%$ & $-0.669 \%$ & $-0.508 \%$ & $-3.422 \%$ \\
\hline 12 months & & & & & & \\
\hline VaR historical & $0.000 \%$ & $-1.658 \%$ & $-0.108 \%$ & $-1.127 \%$ & $-0.535 \%$ & $-4.696 \%$ \\
\hline VaR delta & $-0.007 \%$ & $-2.805 \%$ & $-0.133 \%$ & $-0.989 \%$ & $-0.915 \%$ & $-7.219 \%$ \\
\hline VaR GARCH & $-0.004 \%$ & $-2.754 \%$ & $-0.149 \%$ & $-0.965 \%$ & $-0.805 \%$ & $-5.240 \%$ \\
\hline
\end{tabular}

Source: Authors' calculations based on monthly exchange rates published by the Bank of Latvia

Table 2. Estimated VaR for a position of 1 currency unit of foreign currency in EUR for various currencies, holding periods and confidence level $95 \%$

\begin{tabular}{|c|c|c|c|c|c|c|}
\hline \multirow{2}{*}{$\begin{array}{c}\text { Significance level } \\
1 \text { month }\end{array}$} & \multicolumn{6}{|l|}{$95 \%$} \\
\hline & BYR & PLN & RUB & SEK & UAH & USD \\
\hline VaR historical & $0.000 \%$ & $-0.916 \%$ & $-0.053 \%$ & $-0.364 \%$ & $-0.416 \%$ & $-2.868 \%$ \\
\hline VaR delta & $-0.004 \%$ & $-1.064 \%$ & $-0.071 \%$ & $-0.364 \%$ & $-0.481 \%$ & $-2.896 \%$ \\
\hline VaR GARCH & $-0.001 \%$ & $-0.901 \%$ & $-0.094 \%$ & $-0.316 \%$ & $-0.271 \%$ & $-1.683 \%$ \\
\hline \multicolumn{7}{|l|}{3 months } \\
\hline VaR historical & $-0.001 \%$ & $-1.634 \%$ & $-0.074 \%$ & $-0.531 \%$ & $-0.539 \%$ & $-4.969 \%$ \\
\hline VaR delta & $-0.006 \%$ & $-1.818 \%$ & $-0.114 \%$ & $-0.628 \%$ & $-0.770 \%$ & $-4.896 \%$ \\
\hline VaR GARCH & $-0.002 \%$ & $-1.655 \%$ & $-0.142 \%$ & $-0.579 \%$ & $-0.473 \%$ & $-2.994 \%$ \\
\hline \multicolumn{7}{|l|}{6 months } \\
\hline VaR historical & $-0.001 \%$ & $-2.176 \%$ & $-0.114 \%$ & $-0.796 \%$ & $-0.760 \%$ & $-5.814 \%$ \\
\hline VaR delta & $-0.007 \%$ & $-2.538 \%$ & $-0.149 \%$ & $-0.884 \%$ & $-1.007 \%$ & $-6.763 \%$ \\
\hline VaR GARCH & $-0.003 \%$ & $-2.423 \%$ & $-0.175 \%$ & $-0.846 \%$ & $-0.708 \%$ & $-4.428 \%$ \\
\hline \multicolumn{7}{|l|}{12 months } \\
\hline VaR historical & $-0.006 \%$ & $-2.525 \%$ & $-0.126 \%$ & $-1.398 \%$ & $-0.716 \%$ & $-6.242 \%$ \\
\hline VaR delta & $-0.007 \%$ & $-3.522 \%$ & $-0.188 \%$ & $-1.241 \%$ & $-1.272 \%$ & $-9.255 \%$ \\
\hline VaR GARCH & $-0.005 \%$ & $-3.459 \%$ & $-0.208 \%$ & $-1.211 \%$ & $-1.136 \%$ & $-6.782 \%$ \\
\hline
\end{tabular}

Source: Authors' calculations based on monthly exchange rates published by the Bank of Latvia

Table 3. Estimated VaR for a position of 1 currency unit of foreign currency in EUR for various currencies, holding periods and confidence level 99\% 


\begin{tabular}{|c|c|c|c|c|c|c|}
\hline 1 month & BYR & PLN & RUB & SEK & UAH & USD \\
\hline VaR historical & $-0.001 \%$ & $-1.321 \%$ & $-0.083 \%$ & $-0.458 \%$ & $-0.526 \%$ & $-5.283 \%$ \\
\hline VaR delta & $-0.005 \%$ & $-1.489 \%$ & $-0.102 \%$ & $-0.510 \%$ & $-0.687 \%$ & $-4.078 \%$ \\
\hline VaR GARCH & $-0.001 \%$ & $-1.262 \%$ & $-0.134 \%$ & $-0.443 \%$ & $-0.396 \%$ & $-2.385 \%$ \\
\hline 3 months & & & & & & \\
\hline VaR historical & $-0.007 \%$ & $-2.379 \%$ & $-0.146 \%$ & $-0.621 \%$ & $-0.609 \%$ & $-7.893 \%$ \\
\hline VaR delta & $-0.007 \%$ & $-2.524 \%$ & $-0.166 \%$ & $-0.873 \%$ & $-1.111 \%$ & $-6.874 \%$ \\
\hline VaR GARCH & $-0.002 \%$ & $-2.300 \%$ & $-0.205 \%$ & $-0.805 \%$ & $-0.707 \%$ & $-4.246 \%$ \\
\hline 6 months & & & & & & \\
\hline VaR historical & $-0.008 \%$ & $-3.002 \%$ & $-0.150 \%$ & $-0.815 \%$ & $-0.979 \%$ & $-10.148 \%$ \\
\hline VaR delta & $-0.007 \%$ & $-3.496 \%$ & $-0.221 \%$ & $-1.221 \%$ & $-1.471 \%$ & $-9.468 \%$ \\
\hline VaR GARCH & $-0.004 \%$ & $-3.342 \%$ & $-0.256 \%$ & $-1.168 \%$ & $-1.071 \%$ & $-6.277 \%$ \\
\hline 12 months & & & & & & \\
\hline VaR historical & $-0.008 \%$ & $-3.780 \%$ & $-0.147 \%$ & $-1.506 \%$ & $-0.922 \%$ & $-7.879 \%$ \\
\hline VaR delta & $-0.008 \%$ & $-4.802 \%$ & $-0.288 \%$ & $-1.698 \%$ & $-1.897 \%$ & $-12.908 \%$ \\
\hline VaR GARCH & $-0.006 \%$ & $-4.718 \%$ & $-0.314 \%$ & $-1.658 \%$ & $-1.720 \%$ & $-9.582 \%$ \\
\hline
\end{tabular}

Source: Authors' calculations based on monthly exchange rates published by the Bank of Latvia

From tables 1-3 it is seen that expected losses from outstanding positions vary for different currencies. To compare results of the table for different currencies one has to multiply the estimate by the EUR/currency exchange rate to get loss from the position of 1 EUR. Table 4 shows the $\mathrm{VaR}$ estimates for positions in foreign currency that is equivalent to 1 EUR. It is seen that BYR has the greatest estimated risk, while RUB has the smallest risk. Although UAH was less risky than SEK and PLN as estimated by historical VaR, VaR delta and GARCH methods showed that it could be as risky as PLN and more risky than SEK. Although generally different VaR estimates give similar risk estimates they may vary.

Table 4. Estimated $\mathrm{VaR}$ for a position in foreign currency equivalent to 1 EUR in \% for various currencies and confidence level $95 \%$

\begin{tabular}{|c|c|c|c|r|r|r|}
\hline 12 months & BYR & PLN & RUB & SEK & UAH & USD \\
\hline $\begin{array}{c}\text { VaR } \\
\text { historical }\end{array}$ & $83.302 \%$ & $10.726 \%$ & $-6.031 \%$ & $12.375 \%$ & $-8.325 \%$ & $-8.437 \%$ \\
\hline VaR delta & $95.835 \%$ & $14.966 \%$ & $-8.992 \%$ & $10.987 \%$ & $14.783 \%$ & $12.509 \%$ \\
\hline $\begin{array}{c}\text { VaR } \\
\text { GARCH }\end{array}$ & $61.875 \%$ & $14.696 \%$ & $-9.952 \%$ & $10.723 \%$ & $13.202 \%$ & $-9.167 \%$ \\
\hline
\end{tabular}


Source: authors' calculations based on monthly exchange rates published by the Bank of Latvia

Analysis results show that a company can suffer significant losses due to changes in foreign exchange rates if its outstanding currency positions are not hedged. From 33 companies listed on NASDAQ OMX Baltic Stock Exchange Main list and have significant open currency positions are firms that are using external risk management strategies and such that only internal ones. Conducted analysis shows that estimated by $\mathrm{VaR}$ methods loss from unhedged foreign currency positions for several Baltic companies could be relatively large and shows the need for managing the risk. Although VaR methods may sometimes give imprecise results for longer periods, they give rather good approximations of the losses in shorter periods.

\subsection{Risk management}

A lot of Baltic companies are not using active risk management due to the impossibility of measurement, considering currency exposure measurement too complex. Unfortunately, this is true as in small companies as in bigger ones. In reality, risk measurement is not so complicated task, as companies could use as qualitative (the risk matrix) as quantitative (VaR) analyses and could use consulting firms at the last.

The authors have analysed 33 Baltic companies and only 5 of them (Linas Agro Group, Arco Vara, Olympic Entertainment Group, SAF Tehnika AS, Tallink grupp) are using external strategy of risk management or at least consider to use it, while the majority of companies prefer internal techniques.

The authors have developed the main "step by step" hedging strategy plan used by our companies. Only if it's not possible to hedge risk by the 1 step strategy company goes to the 2 step and so on.

I. First of all, companies are using internal hedging techniques:

First step - all companies are trying to sign contracts in EUR or other currencies hardly pegged to the euro (such as LTL and LVL (before 2014)). This is so called "invoicing in the home currency" strategy.

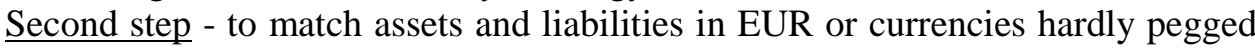
to the euro;

Third step - to net open foreign currency positions in currencies other than EUR, for example USD, UAH, PLN, RUB, SEK, NOK. (AS Silvano Fashion Group, Tallink grupp, TEO LT, Utenos Trikotažas, SAF Tehnika AS, Premia Foods AS, Olympic Entertainment Group, Olainfarm, Grindeks and others).

Forth step - to limit open positions.

II. Secondly, some Baltic companies are using external hedging techniques, mostly Forward rate agreements and Swaps. 
Many Baltic companies' refrain from active management of their foreign exchange exposure, even though they understand that exchange rate fluctuations can affect their earnings and value. They make this decision for a number of reasons that the authors concluded as from financial reports analysis as from interviewing some small and middle companies, which are not listed in Main list:

1. Insignificance of foreign exchange risk, due to the assets and liabilities denomination in EUR or currencies hardly pegged to the euro; therefore they are treated as items free of foreign currency risk (almost 20 companies listed in Main list aren't using any risk management strategies)

2. Companies' managers do not understand why and how to manage foreign exchange exposure, considering financial derivatives as speculative or they argue that such financial manipulations lie outside the firm's field of expertise (mostly in the smaller companies, especially operating in local markets).

3. Denying any exchange risk because it does all its business in home currency (mostly in the smaller companies, especially operating in local markets).

4. Considering that matching is a sufficient hedge for a firm, by covering imports or exports transactions, and foreign subsidiaries finance in local currencies (the most popular for companies that operate in different currencies).

\section{Conclusions, proposals, recommendations}

1. Conducted empirical analysis shows that VaR estimates by historical, delta and GARCH methods give very similar VaR results confirming our first hypothesis $\mathrm{H} 1$ : VaR methods of risk assessment give similar results.

2. Empirical analysis confirms that estimation method is less important for VaR calculation than parameters such as significance level and holding period. $\mathrm{VaR}$ values are greater for longer holding periods and at higher significance levels.

3. Empirical analysis of the most-widely used currencies in the Baltic States confirms that more liquid currencies have smaller foreign exchange exposure comparing with not so commonly used. For example, BYR has the greatest estimated risk, while RUB has the smallest risk. Although UAH was less risky than SEK and PLN as estimated by historical VaR, VaR delta and GARCH methods showed that it could be as risky as PLN and more risky than SEK. Although generally different $\mathrm{VaR}$ estimates give similar risk estimates they may vary.

4. Estimation of possible losses for open currency positions in different companies that operates with other currencies than EUR and LTL and comparing with factual losses in 2011 and 2012, allows the authors confirm 
the second hypothesis $\mathrm{H} 2$ : VaR can be used to measure the part of the currency position that should be hedged.

5. Conducted analysis shows that loss from unhedged foreign currency positions, as estimated by VaR methods, for several Baltic companies could be relatively large and shows the need for managing the risks. Although VaR methods may sometimes give imprecise results for longer periods, they give rather good approximations of the losses in shorter periods.

6. Baltic companies listed on NASDAQ OMX Baltic Stock Exchange Main list are not using active risk management mostly due to the insignificance of foreign exchange risk, due to the assets and liabilities denomination in EUR or currencies hardly pegged to the euro; therefore they are treated as items free of foreign currency risk.

7. The authors have analysed 33 Baltic companies and only 5 of them (Linas Agro Group, Arco Vara, Olympic Entertainment Group, SAF Tehnika AS, Tallink grupp) are using external strategy of risk management or at least consider to use it, while the majority of companies prefer internal techniques. This finding confirms the third hypothesis H3: Baltic companies are mostly using internal hedging techniques.

8. Additional reason for passive risk management is too expensive cost of implementing a currency hedge (transaction costs + interest rate differential between currencies) versus the expected risk contribution from unhedged currency risk.

9. Some of our companies' managers consider that the risk contribution from unhedged currency exposure is relatively low.

10. The analysis of the Baltic companies' foreign exchange exposure management practice shows that our companies are more passive than active. Companies' analysis has highlighted that generally managers in the Baltic countries do not seek to manage currency risk at all, especially smaller ones, mostly because of the lack of knowledge how to manage risk at all.

\section{References}

Aggarwal, R., \& Harper, J. T. (2010). Foreign exchange exposure of "domestic" corporations// Journal of International Money and Finance. In Press, Corrected Proof//http://dx.doi.org/10.1016/j.jimonfin.2010.05.003

Akansha, J. (2013). Forex Risk Management- Internal and External Techniques. Available at http://drakanshajain.blogspot.com/2011/11/forex-risk-management-internal-and.html. [Accessed 02 February 2014].

Allayannis, G., \& Weston, J. (2001). The Use of Foreign Currency Derivatives and Firm Market Value// Review of Financial Studies. No. 14, 2001, pp. 243-276.

Allayannis, G., Ihrig, J., \& Weston, J. (2001). Exchange-rate hedging: Financial versus operational strategies//

American Economic Review, Nr. 91(2). http://dx.doi.org/10.1257/aer.91.2.391.

Annual reports of all Baltic companies listed on NASDAQ OMX Baltic Stock Exchange Main list , 2008-2012 
Artzner, P., F. Delbaen, J.M. Eber, and D. Heath. (1999). Coherent Measures of Risk//Mathematical Finance . No.9, pp.203-228.

Bank of Latvia Statistical Data Base. Available at: http://statdb.bank.lv/lb/Data.aspx?id=118\&lv [Accessed 02 February 2013].

Bao, Y., T.-H. Lee, and B. Saltoglu. (2004). A Test for Density Forecast Comparison with Applications to Risk Management// Technical report, University of California,Riverside.

Bartov, E., \& Bodnar, G. (1994). Firm valuation, earnings expectations, and the exchangerate exposure effect//Journal of Finance. No 49(5). http://dx.doi.org/10.1111/j.15406261.1994.tb04780.x.

Basle Committee on Banking Supervision. (1995). An Internal Model-Based Approach to Market Risk Capital Requirements. Available at http://www. bis.org. [Accessed 23 July 2013].

Basle Committee on Banking Supervision. (1996a). Overview of the Amendment to the Capital Accord to Incorporate Market Risks// Available at http://www. bis.org. [Accessed 15 July 2013].

Basle Committee on Banking Supervision. (1996b). Supervisory Framework for the Use of "'Backtesting"' in Conjunction with the Internal Models Approach to Market Risk Capital Requirements.' Available at http://www.bis.org. [Accessed 23 July 2013].

Batten, J., Mellor, R. \& Wan, V. (1993). Foreign exchange risk management practices and products used by Australian firms// Journal of International Business Studies. Volume 24, Issue 383QTR., pp. 557-573.

Bawa, V. S. (1978). Safety-First, Stochastic Dominance, and Optimal Portfolio Choice// Journal of Financial and Quantitative Analysis. No. 13, pp. 255-271.

Bera, A. K., \& Higgins M. L. (1993). ARCH Models: Properties, Estimation and Testing// Journal of Economic Surveyes, Vol. 7, No. 4, pp.305-366.

Bodnar, G., \& Gebhardt G.(1999). Derivative Usage by Non-Financial Firms in the US and Germany: A Comparative Survey// Journal of International Financial Management and Accounting. Vol. 10, No. 3, pp. 53-87.

Bodnar, G., Marston, R. \& Hayt,G. (1998).Wharton 1998 Survey of Risk Management by U.S. Non-Financial Firms", Financial Management, Winter Vol. 27, No. 4

Dowd, K. (2002). Measuring Market Risk. Chichester// John Wiley \& Sons.

Embrechts, P., McNeil, A. and Frey, R. (2005). Quantitative Risk Management: Concepts, Techniques and Tools. - Princeton University Press, Princeton and Oxford, 2005, pp. 538.

Froot, K., Scharfstein, D., \& Stein, J. (1993). Risk management: Coordinating corporate investment and financing policies// Journal of Finance. No 48(5), pp.1629-58.

Gallati, R. R. (2003). Risk Management and Capital Adequacy// New York: McGraw-Hill.

Jorion, P. (2001). Value at Risk: the New Benchmark for Managing Financial Risk. Donnelley and Sons Company, McGraw-Hill, pp. 531.

Jorion, P. (2006). Value at Risk: The New Benchmark for Managing Financial Risk, 3rd ed. McGraw-Hill, New York, NY, pp. 262-265.

Kuester, K., Mittnik, S. and Paolella, M. S. (2006). Value-at-risk Prediction: A comparison of Alternative Strategies // Journal of Financial Econometrics. Vol. 4, No. 1, pp. 53-89.

Markovich, N. (2007). Nonparametric Analysis of Univariate Heavy-tailed Data. - Wiley Series in Probability and Statistics, pp. 318.

Novak, S. Y. (2011). Extreme Value Methods with Applications to Finance. - Chapman \& Hall/CRC Press 
Pedersen, C. S., and S. E. Satchell. (1998). An Extended Family of Financial-Risk Measures// Geneva Papers on Risk and Insurance Theory. No 23(2), pp.89-117.

Pritsker, M. (1997). Evaluating Value at Risk Methodologies: Accuracy versus Computational Time// Journal of Financial Services Research. No.12, pp. 201-242.

Pritsker, M. (2001). The Hidden Dangers of Historical Simulation// Finance and Economics Discussion. Series 27. Board of Governors of the Federal Reserve System, Washington, D. C.

Taqqu, M. and Bradley, B. (2001). Financial Risk and Heavy Tails. - Elsevier. Princeton and Oxford, pp.63.

Thalassinos, I.E., Ugurlu, E., and Muratoglu, Y. (2012). Income Inequality and Inflation in the EU. European Research Studies, 15(1), 127.

Thalassinos, I.E. et al., (2010). New Dimensions of Country Risk in the Context of the Current Crisis: A Case Study for Romania and Greece. European Research Studies, 13(3), 225-236.

Thalassinos, I.E., Ugurlu, E., and Muratoglu, Y. (2015). Comparison of Forecasting Volatility in the Czech Republic Stock Market. Applied Economics and Finance, 2(1), 11-18.

Thalassinos, I.E., Liapis, K. and Thalassinos, E.J. (2014). The role of the rating companies in the recent financial crisis in the Balkan and black sea area. Chapter book in Economic Crisis in Europe and the Balkans, 79-115, Contributions to Economics, Springer International Publishing, DOI: 10.1007/978-3-319-00494-5$\underline{6}$.

Thalassinos, I.E., Th. Stamatopoulos, D.T. and Thalassinos, E.P. (2015). The European Sovereign Debt Crisis and the Role of Credit Swaps. Chapter book in The WSPC Handbook of Futures Markets (eds) W. T. Ziemba and A.G. Malliaris, in memory of Late Milton Miller (Nobel 1990) World Scientific Handbook in Financial Economic Series Vol. 5, Chapter 20. 